\title{
Protokol Keluar dan Masuk Rumah Selama Pandemi Covid-19
}

\author{
Raja Fitrina Lestari ${ }^{1}$, Lita $^{2}$ \\ ${ }_{1,2}$ Program StudiSarjana Keperawatan, STIKes Hang Tuah Pekanbaru, Riau, Indonesia \\ E-mail: rajafitrinalestari@htp.ac.id.
}

Submitted : 27/01/2021

Accepted: 02/06/2021

Published: 28/06/2021

\begin{abstract}
The spread of COVID-19 in Indonesia has significantly increased and become widespread throughout various areas and countries along with the spike of the number of cases and/or the number of deaths. Therefore, it needs accelerated handling in the form of Large-scale social restrictions (Indonesian: Pembatasan Sosial Berskala Besar or PSBB) in order to curb the spread of COVID-19. The aim of this outreach program is make videos on protocol to leave and enter the house during the COVID-19 pandemic. The method used is to make the videos and then spread them to the community via social media. The aim of this activity is to provide useful information via social media, which is Youtube channel, about the protocol to leave and enter the house during COVID-19 pandemic. The result shows that there are advantages provided to the viewers, and the videos gained 28 likes, 65 subscribers, and have been watched 71 times. Regarding health protocol compliance, it is also hoped to provide assistance program for community by monitoring and reminding them to apply health protocol when both entering and leaving their houses amid the pandemic, and also by intensifying $3 M$ campaign ( maintaining distance, washing hands, wearing masks) as well as $3 T$ campaign (tracing, treatment, testing). Both are equally important to be well implemented in order to curb the spread of COVID-19
\end{abstract}

Keyword: COVID-19, pandemic, video

\section{Abstrak}

Penyebaran COVID-19 di Indonesia saat ini sudah semakin meningkat dan meluas lintas wilayah dan lintas negara yang diiringi dengan jumlah kasus dan/atau jumlah kematian. sehingga diperlukan percepatan penanganan COVID-19 dalam bentuk tindakan Pembatasan Sosial Berskala Besar dalam rangka menekan penyebaran COVID-19 semakin meluas. Tujuan pengabdian masyarakat ini adalah untuk membuat video protokol keluar dan masuk rumah selama masa pandemi COVID-19. Metode yang digunakan dengan cara membuat video yang selanjutnya akan di sampaikan kepada masyarakat melalui media sosial. Tujuan kegiatan ini memberikan Informasi melalui media social yaitu channel Youtube tentang protokol keluar masuk rumah selama masa Pandemi COVID-19.Hasil kegiatan menunjukkan adanya manfaat yang disampaikan oleh viewer dan didapat 28 like, 65 Subscriber dan ditonton sebanyak 71 kali. Harapan selanjutnya dalam meningkatkan kepatuhan masyarakat untuk dapat melaksanakan protocol keluar masuk rumah selama masa Pandemi COVID-19 adalah dengan cara pendampingan dengan memonitor dan mengingatkan masyarakat untuk menerapkan protocol keluar masuk rumah dan juga mengikuti anjuran pemerintah dalam mengerakkan slogan 3M (Menjaga jarak, Mencuci tangan, memakai masker) dan saat ini terdapat juga slogan 3T (Tracing, Treatment, Testing). Yang keduanya sama pentingnya diterapkan dalam memutus mata rantai penularan COVID-19.

Kata kunci : COVID-19, pandemi, video 


\section{PENDAHULUAN}

Coronavirus Disease 2019 (COVID19) adalah penyakit jenis baru yang belum pernah diidentifikasi sebelumnya pada manusia.Virus penyebab COVID-19 ini dinamakan SARS-COV-2. Virus corona SARS-CoV-2 yang menyebabkan penyakit Covid-19 terus menyebar ke berbagai negara dan menyebabkan ribuan orang meninggal dunia sejak pertama kali ditemukan di Kota Wuhan, Hubei, China, pada Desember 2019 (WHO,2020).

Satuan Tugas Penanganan COVID19 mencatat jumlah yang terpapar COVID19 di Indonesia yang tersebar di 34 Provinsi per tanggal 14 November 2020 yakni 5.272 terkonfirmasi, Sembuh 3000, dan 111 Meninggal (covid19.go.id, 2020). Sedangkan di Riau sendiri update kasus COVID-19 mencatat 130 orang terkonfirmasidan 49 orang sembuh (Kurnia, 2020)

Penyebaran COVID-19 di Indonesia saat ini sudah semakin meningkat dan meluas lintaswilayah dan lintas negara yang diiringi dengan jumlah kasus dan/atau jumlah kematian. Peningkatan tersebut berdampak pada aspek politik, ekonomi, sosial, budaya, pertahanan, dan keamanan, serta kesejahteraan masyarakat di Indonesia, sehingga diperlukan percepatan penanganan COVID-19 dalam bentuk tindakan Pembatasan Sosial Berskala Besar dalam rangka menekan penyebaran COVID-19 semakin meluas.

Tindakan tersebut meliputi pembatasan kegiatan tertentu penduduk dalam suatu wilayah yang diduga terinfeksi COVID-19 termasuk pembatasan terhadap pergerakan orang dan/atau barang untuk satu provinsi atau kabupaten/kota tertentuuntuk mencegah penyebaran COVID-19. Pembatasan tersebut paling sedikit dilakukan melalui peliburan sekolah dan tempat kerja, pembatasan kegiatan keagamaan, dan/atau pembatasan kegiatan di tempat atau fasilitas umum (Permenkes, 2020).

Pemerintah melalui Kementerian Kesehatan telah mengeluarkan beberapa kebijakan untuk memerangi Pandemi COVID-19 antara lain seperti penerapan 3M (menggunakan masker, mencucitangan, menjaga jarak) dan 3T (Tracing, Testing, Treatment) yang telah disampaikan melalui berbagai media informasi. Upaya ini dilakukan untuk memutus mata rantai penyebaran COVID-19. Namun tidak menutup kemungkinan sebagian orang yang harus terpaksa keluar rumah untuk melaksanakantugas yang penting, dengan harus berhati-hati untuk meminimalkan risikoterpapar virus. Tindakan yang dilakukan adalah memberikan informasi melalui media social yaitu melalui Channel Youtube bagaimana protocol keluar masuk rumah selama masa pandemic COVID-19.

Adapun tujuan kegiatan ini adalah Memberikan Informasi melalui media social yaitu channel Youtube tentang protocol keluar masuk rumah selama masa Pandemi COVID-19. Penyebaran informasi ini juga untuk melihat respon masyarakat terkait informasi yang diberikan melalui media visual ini.

\section{TARGET DAN LUARAN}

Meningkatkan

kepatuhan masyarakat untuk dapat melaksanakan protocol keluar masuk rumah selama masa Pandemi COVID-19 adalah dengan cara pendampingan dengan memonitor dan mengingatkan masyarakat untuk menerapkan protocol keluar masuk rumah dan juga mengikuti anjuran pemerintah dalam mengerakkan slogan 3M (Menjaga jarak, Mencuci tangan, memakai masker)

\section{METODE PELAKSANAAN}

Metode yang digunakan dengan memberikan pendampingan dan memberikan informasi melalui media video 
mengenai protocol keluar masuk rumah selama masa pandemic COVID-19. Pendampingan yang diberikankepada Masyarakat dengan beberapa metode dan hasil sebagai berikut :

1. Memberikan Informasi melalui media Video

Video yang telah dibuat oleh Tim setelah melalui proses editing

2. Pendampingan

Pendampingan dilakukan dengan membuka kolom komentar pada video yang telah di unggah di channel Youtube "rajafitrina"

3. Penilaian

Penilaian hasil dilihat dari yang memberikan respons etelah video di unggah yaitu "like" sebanyak 28, "ditonton" 71 kali, komentar oleh 2 orang yang menyatakan manfaatakan informasi yang diberikan, dan terdapat 65"subscriber"

\section{HASIL DAN PEMBAHASAN}

Pengabdian masyarakat yang berjudul "Protokol Keluar Masuk Rumah Selama Masa Pandemic COVID-19" telah dilaksanakan dan di unggah di Channel Youtube pengusul yaitu "rajafitrina" padatanggal 10 Agustus 2020. Didapatkan hasil

1. Channel Youtube 'rajafitrina"
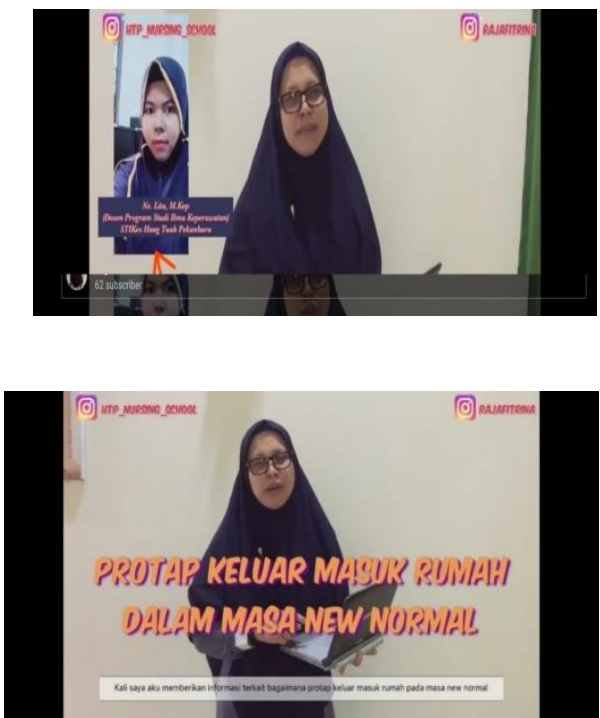

2. Jumlah yang "like"
Respon yang didapat selama 3 bulan di tayangkan didapat 28

3. Jumlah yang "Subscribe"

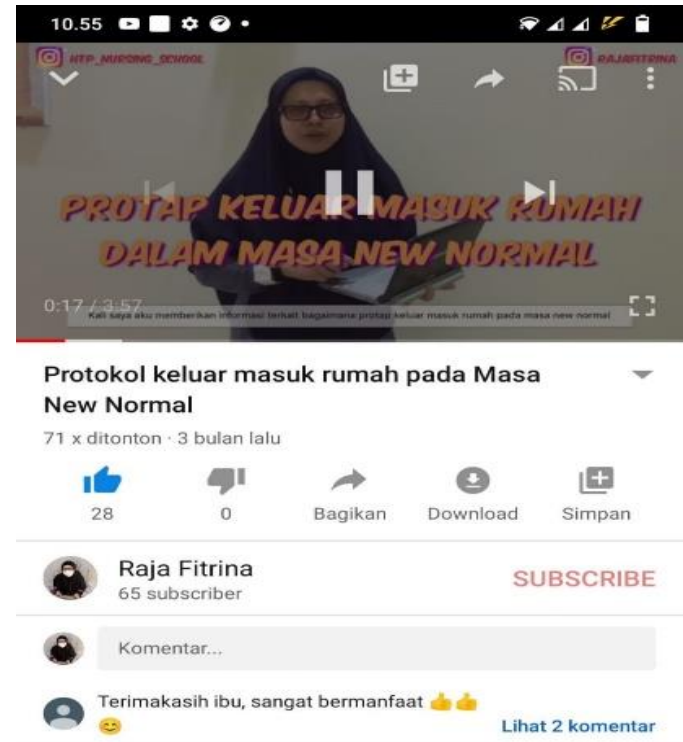

4. Jumlah "komentar"dan ditonton

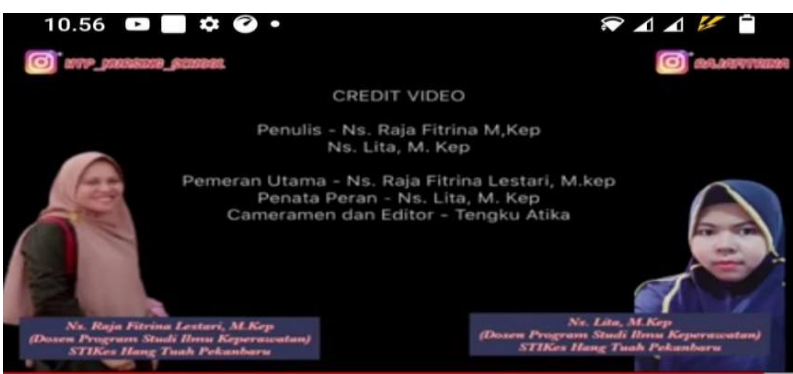

Protokol keluar masuk rumah pada Masa New Normal

71 x ditonton 3 bulan lalu

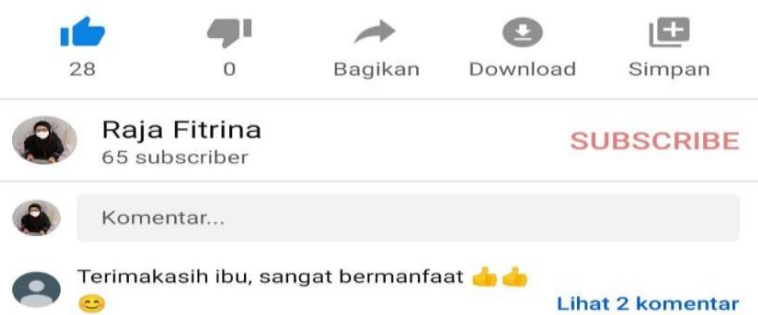

Berikutnya

Putar otomatis 

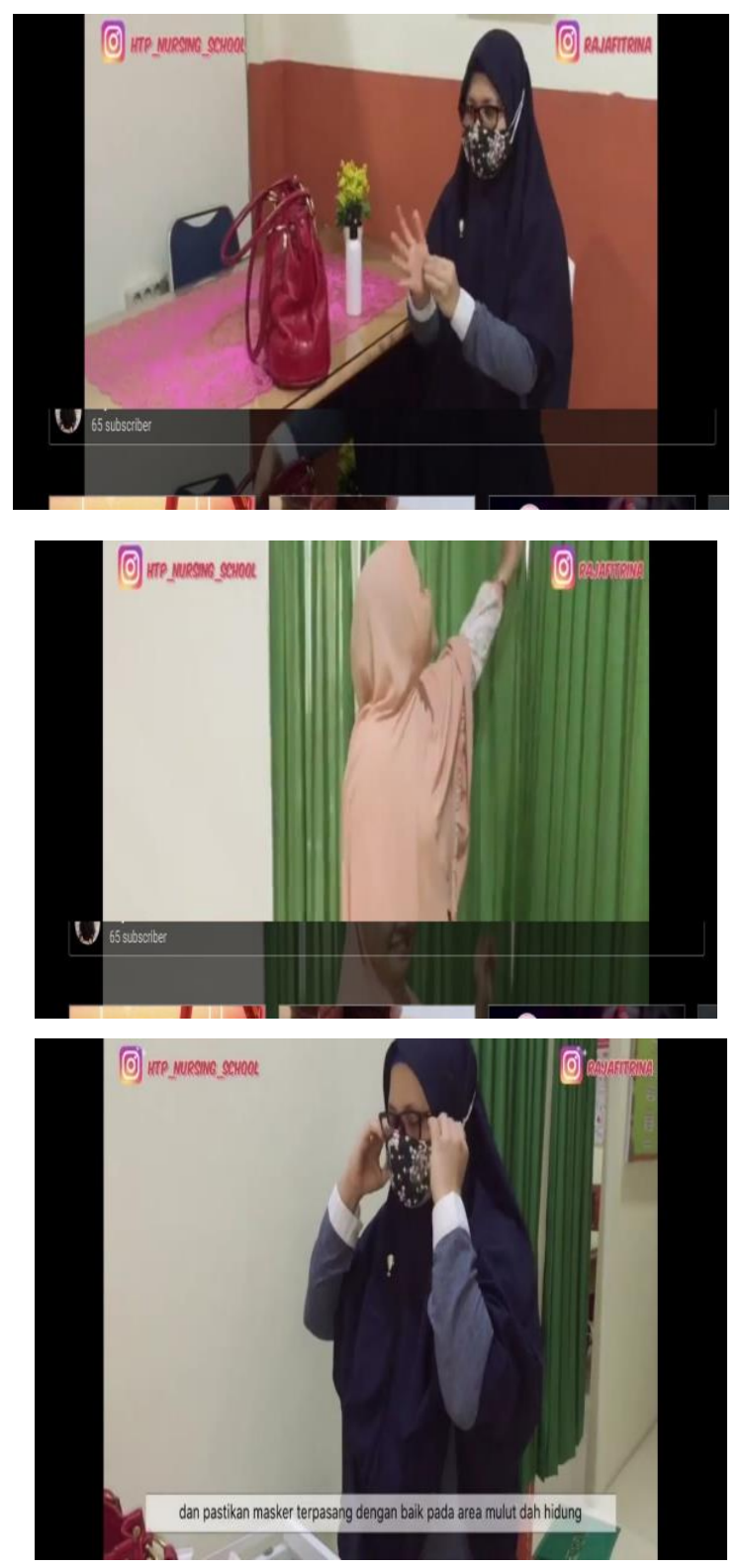

Gambar 1,2,3. Kegiatan edukasi

\section{KESIMPULAN DAN SARAN}

\section{Kesimpulan}

Masa Pandemi COVID-19 hingga saat ini belumberakhir, yang mengharuskan kita untuk tetap tinggal di rumah untuk memutus rantai penyebaran virus corona, ini juga merupakan himbauan Pemerintah agar kita mendukung penyelesaian masalah Pandemi global ini. Namun kenyataannya tidak semua orang bias tetap tinggal di rumah, pasalnya kebutuhan orang berbeda-beda. Masyarakat belum terlalu patuh dalam menjalankan himbauan pemerintah jika mengharuskan untuk beraktifitas diluar rumah. Masyarakat yang belum patuh dan belum menerapkan protocol keluar masuk rumah selama masa pandemic COVID-19 telah diberikan edukasi melalui video yang ditayangkan dan dilakukan pendampingan dalam menerapkan protocol kesehatan tersebut sehingga dapat dilaksanakan jika beraktifitas diluar rumah.

\section{Saran}

Disarankan Masyarakat banyak yang menonton video dan menyukai video tersebut. Memutar video tersebut dalam setiap kegiatan masyarakat. Menganjurkan untuk tetapmengikuti pola hidup sehat dan perilaku hidup bersih

\section{UCAPAN TERIMAKASIH}

Ucapan terimakasih kepada Timpengusul, kepada Ketua STIKes Hang Tuah Pekanbaru, Ketua dan Tim Penilai P3M dan seluruh yang terlibatdalam penyelesaian pelaksanaan pengabdian masyarakat ini serta para pencinta hasil video protocol keluar masuk rumah selama masa Pandemi Covid-19 yang telah memberikan dukungan dan moril semoga video inidapat bermanfaat dan diterapkan dalam kehidupan.

\section{DAFTAR PUSTAKA}

Kemenkes.(2020). RI. Pedoman pencegahan dan pengendalian COVID-19. pdf, Diakses pada 4 April 2020

Permenkes 9 tahun 2020 tentang Pedoman PSBB dalam rangka Percepatan Penanganan COVID-19

World Health Organization (WHO). 2020. $\mathrm{h}$ ttps://www.who.int/healthtopics/coronavirus. Diakses 18 April 
2020.

World Health Organization (WHO).2020. Clinical management of severe acute Respiratory infection when novel coronavirus (nCoV) infection is suspected.

https://www.who.int/internalpublications-detail/clinicalmanagement-of-severeacuterespiratory-infection-whennovel-coronavirus-(ncov)-infectionis-suspected. Diakses 11 Januari 2020.

World Health Organization (WHO).2020. Infection prevention and control during health care when novel coronavirus (nCoV) infection is suspected. https://www.who.int /publications-detail/infectionprevention-and-control-duringhealth-care-when-novelcoronavirus(ncov)-infection-is-suspected.Diakses 13 Maret 2020.

World Health Organization (WHO).2020. WHO recommendations to reduce risk of transmission of emerging pathogens from animals to humans in live animal markets. https://www.who.int/healthtopics/coronavirus/whorecommendations-to-reduce-riskoftransmission-of-emergingpathogens-from-animals-to-humansin-live-animal-markets. Diakses 13 Maret 2020.

World Health Organization (WHO).2020. Advice for public. https://www.who.int /emergencies/diseases/novelcoronavirus-2019/advice-forpublic.Diakses 20 Maret 2020

World Health Organization (WHO).2020. Home care for patients with suspected novel coronavirus (nCoV) infection presenting with mild symptoms and management of contacts. https://www.who.int/internal- publications-detail/home-care-forpatients-withsuspected-novelcoronavirus-(nCoV)-infectionpresenting-with-mild-symptomsandmanagement-of-contacts. 